\title{
Holding the Crucible: Growing a Portfolio of ENGINEERING LEADERSHIP ELECTIVE COURSES AND A COMMUNITY OF EDUCATORS
}

\author{
Annie Simpson ${ }^{1}$, Mike Klassen ${ }^{1}$, and Doug Reeve ${ }^{1,2}$ \\ ${ }^{1}$ Institute for Leadership Education in Engineering \\ ${ }^{2}$ Department of Chemical Engineering and Applied Chemistry \\ University of Toronto \\ annie.simpson@utoronto.ca
}

\begin{abstract}
Engineering leadership programs in Canada have grown in recent years, captured by a literature that mostly documents course design and outcomes. This paper addresses a gap in understanding how courses evolve over time, and how instructors can be better supported to teach engineering leadership. Findings show detailed trajectory of elective course development, instructor profiles, results of learning outcomes mapping, and approaches to supporting a group of leadership instructors.
\end{abstract}

Keywords: Engineering leadership, teaching support, sessional instructor, elective courses, learning outcomes

\section{INTRODUCTION}

The field of engineering leadership education is growing in both the United States and in Canada and different notions of leadership have emerged in different contexts [1], [2]. This paper reports on the experience of overseeing a significant growth in engineering leadership courses at one university, taught by a team of leadership practitioners, scholars and business people.

Recent papers have shown the breadth of engineering leadership program and organizational design [1], and many others have given detailed accounts of individual programs or courses [3]-[9]. Other studies have investigated the profile of those who teach engineering leadership [10]. However, the literature is quite sparse when it comes to the operational and management approaches to supporting growing numbers of engineering leadership elective courses.

This paper will shed light on our experiences supporting a diverse suite of elective courses on engineering leadership at the graduate and undergraduate levels taught at the Institute for Leadership Education in Engineering (ILead) at the University of Toronto, by a range of different instructors. We will document the history of our growth and discuss key practices utilized to foster cohesion across individual courses, and build a committed community of educators.

In 2007, we offered the first elective course on engineering leadership. Since that time, numerous instructors have joined our team and now 11 individual courses are offered annually (some with multiple sections) to over 500 students. Hiring new instructors and building a collegial community among them has been critical to establishing and maintaining a culture that reflects the philosophy we teach.

Deep in ILead's culture is the belief that leadership starts with the self and that self-knowledge and selfreflection are required to be effective as leaders. Leadership is challenging work and 'tips and tricks' can only go so far. Skillful leadership depends on an ability to self-reflect, to know one's strengths and appreciate the strengths of others, to build strong relationships and to be willing to question one's beliefs and assumptions. The high value placed on self-development and personal reflection is evident in every course whether the focus is career management, leading in organizations, professional presentations, story-telling, the science of emotional intelligence, project management or ethics and equity.

This paper will address three main areas. First, we will share a history of how we grew a suite of elective courses in our institutional context, including practices for recruiting instructors and supporting them in designing courses. We also discuss the profile of our instructors, from tenured faculty members to a range of sessional instructors [11]. Second, we delve into our programmatic learning outcomes and map these to individual courses. The emphasis on self-leadership is evident in all of our courses and this discussion will reveal the philosophy of leadership from which we teach. Lastly, given the sheer number of courses and instructors, we have built a set of 
practices and norms that support a collegial community among our teaching team. A discussion of how this community works is included.

\section{HISTORY OF COURSES AND PROFILE OF INSTRUCTORS}

\subsection{History of Courses}

Eleven distinct courses on engineering leadership are currently offered by ILead. They differ in their topic, their instructor, and the type of students that they are offered to. In this section, we explain the growth process of courses, and summarize in Table 1 the key features of each course. Our aim is to emphasize the emergent and organic nature of ILead course development over ten years. We will also analyze the demographics of our instructors and comment on the strengths and weaknesses of the current profile of our leadership instructors.

Our first course, 'Leadership and Leading in Groups and Organizations' was developed and launched in 2007, by a recently retired senior business leader with a full career of international leadership experience [4]. The profile and legitimacy afforded to the instructor was an important feature in getting the course approved by Faculty Council. On the pedagogical side, there was support offered by educationally trained staff to develop highly interactive and reflective activities to enhance student learning. At this stage, it was "all hands-on deck" and as it was the only course offered, nearly all members of the (then small) team assisted with both its content, development and delivery.

The second course (2008) entitled 'The Cognitive and Psychological Foundations of Leadership' was developed and taught by a recent $\mathrm{PhD}$ graduate in applied psychology and human development. She focused on leadership development of young people and brought an intensely experiential teaching style, modeled on top pedagogy and emerging psychological research. This course was a balanced complement to our first course.

Next came a course (2009) entitled 'Concepts and Applications of Authentic Leadership.' This course, taught by two management consultants and executive coaches focused on values-led leadership and guided students through a number of frameworks and models that the instructors had been using with professionals. This course was offered to graduate students.

The fourth course entitled 'Positive Psychology for Engineers' was also taught by the Instructor of Cognitive and Psychological Foundations.
The fifth course, 'Engineering Leadership' was an adaptation of 'Leadership and Leading in Groups and Organizations' which then shifted to become a graduate course. Engineering Leadership has been taught by an engineering professor, and the Director of ILead. There are plans to expand this course to become a foundational, pre-requisite for other ILead courses.

The next few courses to launch were 'The Power of Story: Discovering Your Leadership Narrative,' co-taught by the Assistant Director of ILead and a colleague in the Engineering Communications Program and offered to senior undergraduates [12], and 'Leadership and Project Management', taught by a consultant and business instructor, offered to both undergraduate and graduate students.

These were followed in 2014-2015 with an engineering careers course, taught by the founder of a career consulting firm and graduate of engineering, and an emotional intelligence course, taught by an executive coach. Both of these courses are offered to graduate students. See Appendix B for a table summarizing key aspects of each course.

\subsection{Profile of Instructors}

As is clear from this history, very few of our instructors are tenure-streamed. In fact, half of our teaching team are fully employed elsewhere and have chosen to teach and contribute to our program and to our mission. Another point of interest is that until now we have not done an explicit search for an instructor. Everyone has been recruited through relationships with team members, and in all cases the focus and content of the course has been built by the instructor based on their expertise. The main exception to this pattern is the adaptation of the first course 'Leadership and leading and groups and organizations' to the undergraduate course on Engineering Leadership, which is now offered in 2 sections and is set to be expanded further in the near future.

Another important pattern of course development is the fact that many courses are first developed and tested as graduate courses. Where there is significant demand among undergraduates, as with the psychology and leadership courses, they are then passed again through curriculum governance to be approved for offering in the undergraduate course calendar.

Turning our attention to the demographic profile of the instructors, we see some patterns: All 10 instructors are Caucasian, 7 of 10 are male, and 9 of 10 have stable, long-term employment (either by the institute itself, their own consulting firm, or other). The great strengths of this 
team are that most of our instructors have rich and credible experience in the field of leadership practice, others are known for their commitment to teaching. Also, within the instructor team there is a shared emphasis on self-development and self-awareness, which is reflected in numerous assignments, many of which are iterative, as a core assessment method (requiring a commitment engagement with each student in the class). Another strength is the blend of engineers, former engineers, and people from other disciplines and contexts. This helps ensure that the courses are contextualized for engineering students, while exposing them to theories and perspectives from a range of disciplines. Lastly, to date there has been extremely high retention among the instructors - in all courses, the 'founding' instructor is still the lead (or co-lead) on teaching the course.

This segues into some of the challenges and critiques. Because of the individualized nature of the course design, and the high retention rate to date, courses are closely tied to individuals who teach them, making the overall suite of courses vulnerable to transition and succession. In terms of diversity, there is clearly a mismatch between the instructors and $\mathrm{U}$ of $\mathrm{T}$ students, a minority of which are Caucasian. Also from a diversity perspective, the sessional nature of instructor positions (contract on a term-by-term basis, low salary) mean that the opportunity to teach engineering leadership is biased towards "classic" contract faculty [11] who are established in their career and able to afford teaching "for the love of it". There is an intersection between the income (class) and race of our instructors that could make us vulnerable to overlooking systemic issues facing engineering students, especially given the long-standing barriers to entry in the profession for women and people of colour.

\section{LEARNING OUTCOMES INTEGRATION}

Given immense challenge of establishing engineering leadership as a legitimate subject of study and research in a faculty of engineering, it makes sense that the windows of opportunity for developing courses on this topic were few. This helps to make sense of the mix of graduate and undergraduate courses, and the strategic approach of recruiting instructors first, and then having them build course syllabi that fit the context, before moving the new courses through the governance process. This is a classic example of strategy making [13], [14] as a pattern of both intended and emergent actions that could not have been predicted in advance..

From a theoretical perspective, an important student leadership theorist who influenced the direction and perspective of all programming coming from the institute was Susan Komives and her student leadership identity development model, also known as the social change model of leadership development [15], [16]. This theory came from outside of engineering, but was integrated into a crucial early funding application, and thus diffused through co-curricular offerings and the design of key activities in the first course.

The first three courses represented a very wide range of disciplinary perspectives: from an analytical engineering approach to leadership in a business context, to a radical experiential, psychological approach to leadership and self-actualization, to an integrated model of values and coaching coming from the corporate leadership consulting sector.

The recognition of this diversity, especially as the number of courses and co-curricular programs increased, led to a series of different efforts to synthesize and develop a core set of learning outcomes that we might be able to evaluate our progress against. At least five distinct efforts can be traced over the last decade, each making important contributions in a cumulative fashion. Some efforts were driven by internal motivations by individuals in the institution, others by external governance review processes such as the self-study in 2015 .

Table 1: History of learning outcomes initiatives

\begin{tabular}{|c|c|c|c|}
\hline 華 & $\begin{array}{l}\text { Nature of } \\
\text { initiative }\end{array}$ & Drivers & Outputs \\
\hline ঠ̊̊ & $\begin{array}{l}\text { Before the } \\
\text { program was } \\
\text { granted funding } \\
\text { by the Provost, } \\
\text { significant } \\
\text { thought went into } \\
\text { articulating the } \\
\text { program learning } \\
\text { outcomes }\end{array}$ & $\begin{array}{l}\text { Internal, co- } \\
\text { leaders and } \\
\text { engineering } \\
\text { senior } \\
\text { executive }\end{array}$ & $\begin{array}{l}\text { Some guiding } \\
\text { documents that } \\
\text { assisted with } \\
\text { early program } \\
\text { design and } \\
\text { development. }\end{array}$ \\
\hline$\stackrel{\circ}{\circ}$ & $\begin{array}{l}\text { Individual } \\
\text { pushing for } \\
\text { articulation of } \\
\text { learning } \\
\text { outcomes }\end{array}$ & $\begin{array}{l}\text { Internal, } \\
\text { strategic } \\
\text { planning } \\
\text { team }\end{array}$ & $\begin{array}{l}\text { Learning } \\
\text { outcomes that } \\
\text { related to four } \\
\text { domains: Self, } \\
\text { Team, } \\
\text { Organization, } \\
\text { Society }\end{array}$ \\
\hline  & $\begin{array}{l}\text { Pair seeking to } \\
\text { map and assess } \\
\text { learning } \\
\text { outcomes through } \\
\text { an analytical } \\
\text { process }\end{array}$ & $\begin{array}{l}\text { Internal, } \\
\text { pairing }\end{array}$ & $\begin{array}{l}\text { Detailed } \\
\text { spreadsheet of } \\
\text { activities and } \\
\text { learning } \\
\text { outcomes that } \\
\text { did not generate } \\
\text { further action }\end{array}$ \\
\hline
\end{tabular}




\begin{tabular}{|c|c|c|c|}
\hline 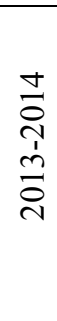 & $\begin{array}{l}\text { Strategic } \\
\text { planning group } \\
\text { driving a } \\
\text { reflective process } \\
\text { to land on } \\
\text { learning } \\
\text { outcomes for self- } \\
\text { study }\end{array}$ & $\begin{array}{l}\text { External, } \\
\text { internal }\end{array}$ & $\begin{array}{l}\text { Consolidated list } \\
\text { of learning } \\
\text { outcomes } \\
\text { organized by } 4 \\
\text { levels of } \\
\text { leadership and } \\
\text { by reflection vs. } \\
\text { action }\end{array}$ \\
\hline 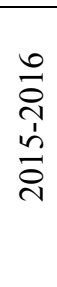 & $\begin{array}{l}\text { Coordinated self- } \\
\text { assessment by } \\
\text { staff, instructors } \\
\text { and faculty }\end{array}$ & $\begin{array}{l}\text { Internal, } \\
\text { consultative }\end{array}$ & $\begin{array}{l}\text { Partially } \\
\text { complete "map" } \\
\text { of learning } \\
\text { outcomes across } \\
4 \text { domains for all } \\
\text { courses and } \\
\text { programs. }\end{array}$ \\
\hline
\end{tabular}

A breakdown of the most and least emphasized learning outcomes for each of the four levels of leadership are shown in Table 2 below. These are the results of a recent exercise whereby each instructor assessed the contribution of their course to each learning outcome using a simple scale from 0 (no focus or content in offering) to 3 (high focus and deep engagement).

Table 2: Most and Least Emphasized Learning Outcomes

\begin{tabular}{|c|c|c|}
\hline Level & Most Emphasized & Least Emphasized \\
\hline$\frac{\Psi}{\infty}$ & $\begin{array}{l}\text { - Uncover and } \\
\text { challenge thoughts, } \\
\text { assumptions, habits } \\
\text { and mental models } \\
\mathbf{( 2 . 7 / 3 . 0 )} \\
\text { - Use self- } \\
\text { exploration and life } \\
\text { lessons in the pursuit } \\
\text { of life-long self- } \\
\text { improvement and } \\
\text { wisdom (2.8/3.0) }\end{array}$ & $\begin{array}{l}\text { - Recognize that self- } \\
\text { confidence is a critical } \\
\text { asset and cultivate it so } \\
\text { as to increase their } \\
\text { capacity to create } \\
\text { change }(\mathbf{1 . 8 / 3 . 0 )} \\
\text { - Interpret their } \\
\text { worldview in light of } \\
\text { the multi-layered nature } \\
\text { of their own and others' } \\
\text { identity (e.g. race, } \\
\text { gender, class, language, } \\
\text { country and family of } \\
\text { origin) (1.6/3.0) }\end{array}$ \\
\hline
\end{tabular}

CEEA17; Paper 44

University of Toronto; June 4-7, 2017

\begin{tabular}{|c|c|c|}
\hline$\underset{\tilde{\varpi}}{\stackrel{\Xi}{\oplus}}$ & $\begin{array}{l}\text { - Listen actively to } \\
\text { team members. } \\
(\mathbf{2 . 6 / 3 . 0 )} \\
\text { - Recognize and } \\
\text { leverage both their } \\
\text { own strengths, and } \\
\text { the strengths of } \\
\text { others to contribute } \\
\text { to team success. } \\
\mathbf{( 2 . 6 / 3 . 0 )} \\
\text { - Promote an open } \\
\text { and effective } \\
\text { exchange of ideas } \\
\text { and knowledge to } \\
\text { support completion } \\
\text { of a shared } \\
\text { undertaking. } \\
(\mathbf{2 . 6 / 3 . 0 )}\end{array}$ & $\begin{array}{l}\text { - Skillfully navigate } \\
\text { tension and conflict. } \\
\mathbf{( 1 . 3 / 2 . 0 )} \\
\text { - Leverage diversity for } \\
\text { its role in stimulating } \\
\text { learning, debate and } \\
\text { innovation. (1.6/2.0) } \\
\text { - Understand and apply } \\
\text { team development } \\
\text { theory. (1.6/2.0) }\end{array}$ \\
\hline 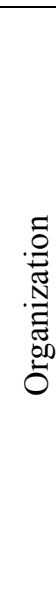 & $\begin{array}{l}\text { - Mobilize their } \\
\text { talents and passions } \\
\text { to contribute to an } \\
\text { organizational } \\
\text { vision. }(\mathbf{2 . 0 / 3 . 0 )} \\
\text { - Apply appropriate } \\
\text { analytical tools and } \\
\text { decision-making } \\
\text { models in response } \\
\text { to different kinds of } \\
\text { organizational } \\
\text { change. }(\mathbf{1 . 6 / 3 . 0 )}\end{array}$ & $\begin{array}{l}\text { - Critically analyze } \\
\text { how organizational } \\
\text { structures and the } \\
\text { division of power drive } \\
\text { individual and team } \\
\text { behavior within an } \\
\text { organization. (1.1/3.0) } \\
\text { - Identify elements of } \\
\text { organizational vision, } \\
\text { mission and values, and } \\
\text { be able to articulate } \\
\text { where these align with } \\
\text { their personal vision, } \\
\text { mission and values } \\
(\mathbf{1 . 3 / 3 . 0 )}\end{array}$ \\
\hline $\begin{array}{l}\frac{\overrightarrow{0}}{8} \\
\stackrel{0}{0}\end{array}$ & $\begin{array}{l}\text { - Describe their role } \\
\text { as engineers within } \\
\text { the context of } \\
\text { society's } \\
\text { complexity, and } \\
\text { evolve this over their } \\
\text { lifetimes. Society is } \\
\text { shaped by many } \\
\text { systems: politics, } \\
\text { power, influence, } \\
\text { culture, government, } \\
\text { the private sector, } \\
\text { and economics. } \\
\text { Reflect on their role } \\
\text { as engineers so as to } \\
\text { enable better } \\
\text { decisions amidst this } \\
\text { complexity and } \\
\text { ambiguity. (1.6/3.0) }\end{array}$ & $\begin{array}{l}\text { - Critically analyze } \\
\text { problems in ways that } \\
\text { incorporate a broader } \\
\text { awareness of economic, } \\
\text { political and global } \\
\text { systems. (0.8/3.0) } \\
\text { - Recognize their own } \\
\text { and others' social } \\
\text { identity (power and } \\
\text { privilege) and reflect } \\
\text { critically on their own } \\
\text { place in the world. } \\
\text { (1.0/3.0) } \\
\text { - Apply engineering } \\
\text { ethics with the social } \\
\text { context in mind } \\
(\mathbf{1 . 0 / 3 . 0 )}\end{array}$ \\
\hline
\end{tabular}


The overall preliminary results of the most recent process are summarized in graphical form in Fig. 1 below to provide a snapshot of the current map of the leadership education curriculum offered by our institute. This shows data for 9 out of 11 existing courses. For a full list of learning outcomes by level of leadership, refer to Appendix A.

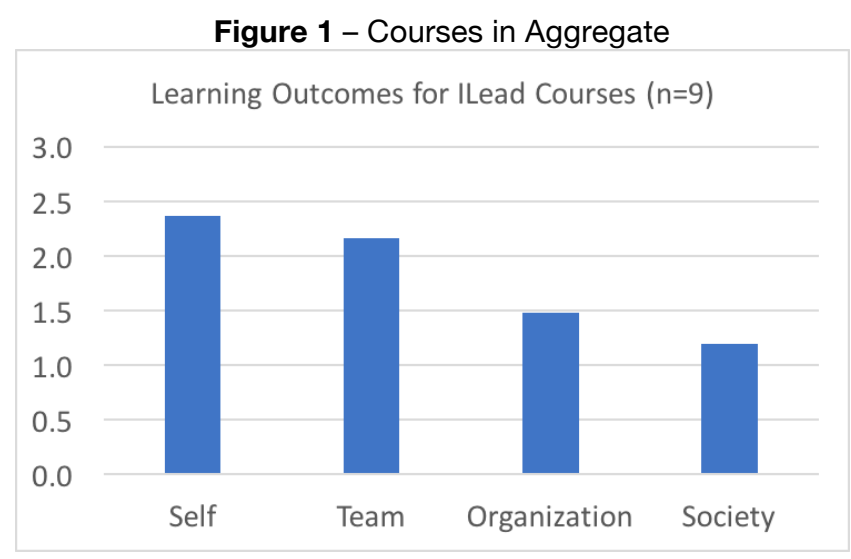

The rationale for the significant weight given to selfleadership learning outcomes across courses is the explicit belief that "leadership begins with the self" [17]. At the same time, the programs which put the most emphasis on organizational leadership learning outcomes tend to be co-curricular programs explicitly targeting students in positions of leadership in clubs and organizations. The new course on Ethics and Equity will bring more emphasis to organizational and societal levels, and particularly the learning outcomes "Apply engineering ethics with the social context in mind", which currently has the lowest emphasis in all courses.

Taking stock of the work done to date from both bottom-up (individual courses) and top-down (overarching learning outcomes) perspectives, there are some useful comparisons to be drawn between this process and the curriculum maps required as part of the CEAB accreditation process [18]. As currently offered, the leadership courses are not mandatory and therefore fall outside of the "minimum path" logic that drives accreditation in Canada. In addition, the structure of our course offerings mean that many different pathways between and among courses are possible for students. Thus, it is not feasible or useful to show how learning activities and outcomes are structured over time, as each student will engage in the courses in a different sequence. However, the "map" is useful for showing the relative emphasis of different courses and programs. In addition, the exercise of having instructors map their own course onto a common set of overarching learning outcomes creates opportunities for more focused discussion about pedagogy and assessment for those specific outcomes. For example, how does one support students to challenge their own assumptions and mental models? And what is a fair and appropriate way to assess that learning outcome? The framing provided by the learning outcomes supports a more tangible exchange of tacit knowledge, and thus can more deeply engage the community of practice [19] of those who teach engineering leadership in a university setting.

The process of mapping learning outcomes is still ongoing. New courses being developed need to be mapped, and existing courses undergoing a transition in instructor are also ripe for reassessment through this framework. The teaching team continues to grow, and this framework provides a starting point for increasing integration and cross-course learning exchange for the instructors. It also provides a starting point for future work to develop an engineering leadership minor, which would involve a structured sequence of courses that would benefit from clear scaffolding of learning outcomes and reinforcement across courses.

\section{COMMUNITY BUILDING}

In our early days, we were a small team so we were all familiar with each other's work. As our suite of courses and programs grew, it became important to find ways of staying connected and sharing best practice. We began convening our instructor group 2-3 times per year with three goals in mind. First, we wanted to establish a supportive community and enhance the experience of our instructors. Second, we wanted to engage in reflective practice on our teaching - to do this effectively requires community, as trust is necessary for instructors to share their uncertainties or to be open with their own learning goals. As we are leadership educators with a philosophical thrust towards self-development and selfreflection, it's critical that we model what we teach. Third, we want to learn from one another. Our team of instructors comes with such rich experience and often with practiced methods and pedagogy for guiding students in their learning. We all want to benefit from these approaches while holding a space where instructors inspire each other and their teaching.

As our program has grown, an additional challenge has been to familiarize our instructor group, who are mostly sessional instructors, with the co-curricular programs that ILead delivers. And so, another element of our tri-annual meetings is to familiarize instructors with what's happening in the Institute at large. As new instructors join our team they are offered support in the course design process. This support includes support in clarifying their learning outcomes and then designing appropriate 
assessment methods and rubrics. At times, there may also be coaching related to class-room practice.

At our Instructor gatherings, we typically use at least one hour to become more familiar with a particular course or to be guided through an exercise that is central to said course. We take turns so that each year, we all get to engage in a deeper way with three of our courses. Through this process, relationships are strengthened and other instructors get to reflect on how the 'course of the day' and its pedagogy relate to their own teaching.

\section{CONCLUSIONS}

Our first course launched 10 years ago and we now have a suite of 11 unique courses, some of which are offered multiple times each year. We have been very fortunate to attract instructors who enjoy teaching and find great meaning in connecting with engineers in such creative and meaningful ways. However, there is work to be done in building the resilience and diversity of our team. We are also acutely aware of the need to diversify in our instructor team and the systemic challenges (i.e. Sessional employment) that this overlaps with. We have grown this suite of courses by taking an opportunistic and highly entrepreneurial approach. As we look ahead to the next phase, it is time to take stock, re-calibrate our learning outcomes and work to build the next generation of course instructors.

\section{References}

[1] M. Klassen, D. Reeve, C. Rottmann, and R. Sacks, "Charting the Landscape of Engineering Leadership Education in North American Universities," presented at the 2016 ASEE Annual Conference \& Exposition, New Orleans, LA, 2016.

[2] R. Paul and L. G. Cowe Falls, "Engineering Leadership Education: A Review of Best Practices," presented at the 2015 ASEE Annual Conference \& Exposition, Seattle, WA, 2015

[3] S. Alajek, A. Ham, H. Murdock, and J. Verrett, "Blurring the Line Between For-Credit Curricular and Not-forCredit Extracurricular Engineering Learning Environments," in Proceedings of the Canadian Engineering Education Association, 2013.

[4] D. Colcleugh and D. Reeve, "Translating a corporate leadership philosophy and practice to the engineering classroom," Proceedings of the Canadian Engineering Education Association, 2013.

[5] R. V. Gonzalez, R. T. Schoephoerster, and J. Townsend, "Engineering Leadership: A New Engineering Discipline," presented at the 2015 ASEE Annual Conference \& Exposition, Seattle, WA, 2015.

[6] M. R. Ha, "Experiential learning in leadership development: Select program at McMaster University," Proceedings of the Canadian Engineering Education Association, 2013.
[7] A. Hsiao, "Developing engineering managers: The master of engineering management program at Memorial University of Newfoundland," Proceedings of the Canadian Engineering Education Association, 2013.

[8] R. H. McCuen, "A course on engineering leadership," Journal of Professional Issues in Engineering Education and Practice, vol. 125, no. 3, pp. 79-82, 1999.

[9] D. E. McMartin, "Service Learning and Team Work Elements of Leadership," in Proceedings of the Canadian Engineering Education Association, 2013.

[10] W. J. Schell and P. J. Kauffmann, "Engineering Leadership: Faculty Perceptions and Profiles," presented at the 2016 ASEE Annual Conference \& Exposition, New Orleans, LA, 2016.

[11] I. Rajagopal, Hidden academics: Contract faculty in Canadian universities. Toronto, ON: University of Toronto Press, 2002.

[12] P. Kinnear and A. Simpson, "Narrative as a Pedagogical Approach to Teaching Leadership and Engineering," in Proceedings of the Canadian Engineering Education Association, Halifax, NS, 2016.

[13] C. Hardy, A. Langley, H. Mintzberg, and J. Rose, "Strategy formation in the university setting," The Review of Higher Education, vol. 6, no. 4, pp. 407-433, Summer 1983.

[14] H. Mintzberg, The rise and fall of strategic planning. Pearson Education, 2000.

[15] S. R. Komives, J. E. Owen, S. D. Longerbeam, F. C. Mainella, and L. Osteen, "Developing a leadership identity: A grounded theory," Journal of College Student Development, vol. 46, no. 6, pp. 593-611, 2005.

[16] S. R. Komives, S. D. Longerbeam, J. E. Owen, F. C. Mainella, and L. Osteen, "A leadership identity development model: Applications from a grounded theory," Journal of College Student Development, vol. 47, no. 4, pp. 401-418, 2006.

[17] ILead, "Visioneering: ILead's vision, values, philosophy, and mission," Institute for Leadership Education in Engineering, Toronto, 2012.

[18] Canadian Engineering Accreditation Board, "2015 Accreditation Criteria and Procedures," Engineers Canada, Ottawa, ON, 2015.

[19] J. Lave and E. Wenger, Situated learning: Legitimate peripheral participation. Cambridge University Press, 1991. 
APPENDIX A: Learning Outcomes for ILead

\section{Self-Leadership}

Students will be able to reflect on who they are as a person:

- Identify and articulate their own values, beliefs, talents, passions and vision

- Uncover and challenge thoughts, assumptions, habits and mental models

- Recognize and identify emotions in real-time and be able to learn and grow from them

- Interpret their worldview in light of the multilayered nature of their own and others' identity (e.g. race, gender, class, language, country and family of origin)

- Apply self-assessment tools and inventories that support a greater awareness of their personality and personal preferences.

- Use self-exploration and life lessons in the pursuit of life-long self-improvement and wisdom

Students will be able to actively develop their leadership:

- Demonstrate skill and comfort in taking risks to improve confidence (risks may include actively sharing multiple dimensions of self with others, speaking publicly, engaging in improvisational exercises, interviewing high profile business leaders, leading student clubs or building a new initiative)

- Seek meaningful feedback on their performance in any context and incorporate it, where appropriate, into their actions

- Recognize that self-confidence is a critical asset and cultivate it so as to increase their capacity to create change

- Demonstrate congruence between values and actions.

- Actively undertake life-long learning

Team Leadership

Students will be able to reflect on how they fit into a team:
- Understand and apply team development theory.

- Evaluate group dynamics and gain awareness of strategies for building a cohesive team

- Practice compassion and seek to understand the viewpoint of others.

Students will be able to take an active role in leading teams towards impact and success:

- Listen actively to team members.

- Recognize and leverage both their own strengths, and the strengths of others to contribute to team success.

- Promote an open and effective exchange of ideas and knowledge to support completion of a shared undertaking.

- Solicit and provide actionable, high quality feedback that empowers teammates to learn and improve.

- Leverage diversity for its role in stimulating learning, debate and innovation.

- Skillfully navigate tension and conflict.

- Promote collaborative problem solving and development of opportunities.

- Facilitate team interactions with attention to both people (process) and problems (tasks).

\section{Organizational Leadership}

Students will be able to reflect on how organizational systems function and how they fit in:

- Identify elements of organizational vision, mission and values, and be able to articulate where these align with their personal vision, mission and values

- Read the currents and culture of an organization (spheres of influence, decision-making models) so as to optimize their own contribution.

- Critically analyze how organizational structures and the division of power drive individual and team behavior within an organization.

- Apply systems thinking to organizational learning and development

Students will be able to take an active role in influencing organizational direction and impact: 
- Mobilize their talents and passions to contribute to an organizational vision.

- Foster collaboration to stimulate organizational growth and innovation

- Apply appropriate analytical tools and decisionmaking models in response to different kinds of organizational change.

\section{Societal Leadership}

Students will be able to reflect on their place in the broader world:

- Describe their role as engineers within the context of society's complexity, and evolve this over their lifetimes. Society is shaped by many systems: politics, power, influence, culture, government, the private sector, and economics. Reflect on their role as engineers so as to enable better decisions amidst this complexity and ambiguity.

- Articulate how their professional and personal life choices are connected to the lives of others around the world.

- Recognize their own and others' social identity (power and privilege) and reflect critically on their own place in the world.

hi

Students will be able to take an active role in shaping the world and contributing to society:

- Critically analyze problems in ways that incorporate a broader awareness of economic, political and global systems.

- Articulate the societal change they'd like to see and feel empowered to act.

- Skillfully communicate engineering know-how to guide positive change in society 


\begin{tabular}{|c|c|c|c|c|c|c|}
\hline Course focus & 䒕 & $\begin{array}{l}\text { Instructor } \\
\text { profile } \& \\
\text { point of } \\
\text { contact }\end{array}$ & $\stackrel{\tilde{N}}{\tilde{n}}$ & : & 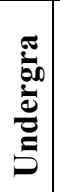 & 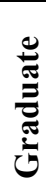 \\
\hline $\begin{array}{l}\text { Leadership in } \\
\text { groups and } \\
\text { organizations }\end{array}$ & 옹 & $\begin{array}{l}\text { Senior } \\
\text { business } \\
\text { leader, retired. } \\
\text { Known from } \\
\text { Departmental } \\
\text { Advisory } \\
\text { Board }\end{array}$ & 40 & 1 & $\mathrm{Y}$ & $\mathrm{Y}$ \\
\hline $\begin{array}{l}\text { Cognitive and } \\
\text { Psychological } \\
\text { Foundations of } \\
\text { Effective } \\
\text { Leadership }\end{array}$ & $\stackrel{\infty}{8}$ & $\begin{array}{l}\text { Cognitive } \\
\text { psychology } \\
\text { PhD, known } \\
\text { from prior } \\
\text { workshops }\end{array}$ & $\begin{array}{l}30 \\
- \\
70\end{array}$ & 2 & $\mathrm{Y}$ & $\mathrm{Y}$ \\
\hline $\begin{array}{l}\text { Authentic } \\
\text { leadership }\end{array}$ & ஓి & $\begin{array}{l}2 \text { management } \\
\text { and leadership } \\
\text { consultants } \\
\text { and coaches, } \\
\text { with personal } \\
\text { connection to } \\
\text { Associate } \\
\text { Director }\end{array}$ & 40 & 1 & $\mathrm{~N}$ & $\mathrm{Y}$ \\
\hline $\begin{array}{l}\text { Positive } \\
\text { psychology for } \\
\text { engineers }\end{array}$ & $\bar{\Xi}$ & $\begin{array}{l}\text { Same } \\
\text { instructor as } \\
\text { Cognitive and } \\
\text { Psychological } \\
\text { Foundations of } \\
\text { Leadership }\end{array}$ & $\begin{array}{l}30 \\
- \\
70\end{array}$ & 2 & $\mathrm{Y}$ & $\mathrm{Y}$ \\
\hline $\begin{array}{l}\text { Engineering } \\
\text { leadership }\end{array}$ & $\frac{*}{\Xi}$ & $\begin{array}{l}\text { ILead Director } \\
\text { and faculty } \\
\text { member in } \\
\text { Chemical } \\
\text { Engineering }\end{array}$ & 50 & 2 & $\mathrm{Y}$ & $\mathrm{N}$ \\
\hline $\begin{array}{l}\text { Storytelling } \\
\text { and personal } \\
\text { narrative }\end{array}$ & $\stackrel{m}{0}$ & $\begin{array}{l}\text { Assistant } \\
\text { director in } \\
\text { collaboration } \\
\text { with } \\
\text { Communicatio } \\
\text { ns instructor }\end{array}$ & 45 & 1 & $\mathrm{Y}$ & $\mathrm{N}$ \\
\hline
\end{tabular}

\begin{tabular}{|c|c|c|c|c|c|c|}
\hline Course focus & 苛 & $\begin{array}{l}\text { Instructor } \\
\text { profile } \& \\
\text { point of } \\
\text { contact }\end{array}$ & $\stackrel{\mathbb{N}}{5}$ & (2) & 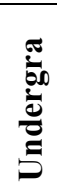 & 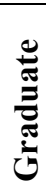 \\
\hline $\begin{array}{l}\text { Project } \\
\text { management } \\
\text { and leadership }\end{array}$ & $\frac{\text { ণ }}{\circ}$ & $\begin{array}{l}\text { Engineer, } \\
\text { consultant and } \\
\text { continuing } \\
\text { studies } \\
\text { instructor with } \\
\text { previous } \\
\text { teaching in } \\
\text { university }\end{array}$ & 40 & 1 & $\mathrm{Y}$ & $\mathrm{Y}$ \\
\hline $\begin{array}{l}\text { Engineering } \\
\text { careers }\end{array}$ & $\frac{n}{2}$ & $\begin{array}{l}\text { Engineer } \\
\text { turned career } \\
\text { counsellor. } \\
\text { Known from } \\
\text { guest sessions } \\
\text { and workshops }\end{array}$ & 30 & $\begin{array}{l}1 \\
- \\
2\end{array}$ & $\mathrm{~N}$ & $\mathrm{Y}$ \\
\hline $\begin{array}{l}\text { Emotional } \\
\text { intelligence }\end{array}$ & 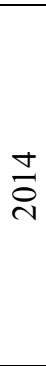 & $\begin{array}{l}\text { Consultant and } \\
\text { business } \\
\text { school } \\
\text { instructor with } \\
\text { prior } \\
\text { connection } \\
\text { through } \\
\text { business } \\
\text { school }\end{array}$ & 30 & 1 & $\mathrm{~N}$ & $\mathrm{Y}$ \\
\hline $\begin{array}{l}\text { Engineering } \\
\text { presentations }\end{array}$ & $\frac{\text { ঠ }}{0}$ & $\begin{array}{l}\text { Same } \\
\text { instructor as } \\
\text { Engineering } \\
\text { Leadership }\end{array}$ & 30 & 1 & $\mathrm{~N}$ & $\mathrm{Y}$ \\
\hline $\begin{array}{l}\text { Ethics and } \\
\text { equity }\end{array}$ & $\frac{\infty}{0}$ & $\begin{array}{l}\text { PhD in } \\
\text { education; } \\
\text { senior } \\
\text { researcher at } \\
\text { institute }\end{array}$ & & & & \\
\hline
\end{tabular}

